Ellysa, Sigid dan Saiful........Reaksi Pasar Atas Pengungkapan Kepatuhan Syariah

Diterima: 15 Nov 2021 Direvisi: 25 Jan 2022 Disetujui: 7 Feb 2022 Dipubikasi: 8 Feb 2022

\title{
REAKSI PASAR ATAS PENGUNGKAPAN KEPATUHAN SYARIAH TERHADAP SAHAM PERUSAHAAN PADA INDEKS SAHAM SYARIAH INDONESIA
}

\author{
Ellysa Kurniati ${ }^{\left.1^{*}\right)}$, Sigid Eko Pramono ${ }^{2)}$, Saiful Anwar ${ }^{3)}$ \\ ${ }^{1}$ Magister Ekonomi Syariah, Institut Agama Islam Tazkia \\ ${ }^{2}$ Departemen Pascasarjana Ekonomi Syariah, Institut Agama Islam Tazkia \\ ${ }^{3}$ Departemen Pascasarjana Keuangan Islam, Institut Teknologi dan Bisnis Ahmad Dahlan \\ *Koresponden email: ellysa114@gmail.com
}

\begin{abstract}
Abstrak
Penelitian ini bertujuan untuk mengetahui reaksi pasar atas pengungkapan kepatuhan syariah terbadap saham perusabaan pada Indeks Saham Syariah Indonesia periode tabun 2011 bingga tabun 2019. Dengan menggunakan metodologi studi peristiwa, penelitian ini menunjukkan bahwa pada 12 dari 14 pengujian atau 86\% dari keseluruhan pengujian yang dilakukan terdapat abnormal return yang positif. Abnormal return yang positif terjadi karena masuknya perusahaan ke dalam Indeks Saham Syariah Indonesia dianggap sebagai sinyal positif oleh para investor, terutama bagi investor ritel dan manajer investasi yang mengkhususkan diri atau hanya fokus untuk. menyalurkan dananya pada produk yang memenubi aspek syariah saja. Sinyal positif ini kemudian disikapi dengan melakukan pembelian atas saham-saham patub syariah pada sekitar periode pengumuman perubaban komposisi saham dalam penghitungan Indeks Saham Syariah Indonesia. Sebingga, bisa disimpulkan babwa pasar memberikan reaksi positif atas informasi kepatuhan syariah. Di sisi lain, berdasarkan hasil penelitian ini, pasar modal Indonesia bisa dikategorikan sebagai pasar modal efisien semi strong form atau pasar modal bentuk. setengah kuat.
\end{abstract}

Kata Kunci: pengumuman ISSI, kepatuhan syariab, reaksi pasar

\section{MARKET REACTION TO SHARIA COMPLIANCE DISCLOSURE WITH COMPANY SHARES LISTED ON THE INDONESIA SHARIA STOCK INDEX}

\begin{abstract}
The purpose of this research is to see how the market reacts to the disclosure of sharia compliance in firm shares on the Indonesian Sharia Stock Index from 2011 to 2019. Using the event study approach, it was discovered that a positive abnormal return was found in 12 of the 14 tests, or 86 percent of all tests conducted. Positive abnormal returns occur as a result of the company's inclusion in the Indonesian Sharia Stock Index, which investors regard as a positive signal, particularly for retail investors and investment managers who specialize or solely focus on channeling their funds to products that meet sharia requirements. This positive signal was subsequently acted upon by making sharia-compliant stock purchases around the time the change in share composition in the calculation of the Indonesian Sharia Stock. Index was announced. As a result, it may be stated that the market reacts positively to sharia compliance information. The Indonesian capital market, on the other hand, can be classified as a semi-strong form of capital market based on the findings of this research.
\end{abstract}

Keywords: ISSI announcement, sharia compliance, market reaction 
FINANCE: a Research Journal on Islamic Finance Vol.07 No. 02 Desember 2021

http//jurnal.radenfatah.ac.id/index.php/i-finance

Ellysa, Sigid dan Saiful.........Reaksi Pasar Atas Pengungkapan Kepatuhan Syariah

\section{PENDAHULUAN}

Pesatnya perkembangan industri keuangan syariah di Indonesia dalam lima tahun terakhir yang mencapai $25 \%$ telah menjadi indikator penting untuk perkembangan dan tonggak sejarah ekonomi negara yang memiliki populasi muslim terbesar (Apriyanti, 2019). Sejalan dengan itu, penelitian tentang pengungkapan/keterbukaan informasi perusahaan pada kategori syariah meningkatkan minat di kalangan para akademisi, praktisi dan pengambil kebijakan (Che Azmi \& Hanifa, 2015). Hal ini menjadi menarik untuk dibahas terkait dengan efektivitas pengungkapan industri keuangan syariah dan pengaruhnya terhadap nilai pasar saham (Dzakiyuddin \& Sutopo, 2020).

Sejalan dengan berkembang pesatnya keuangan syariah yang merupakan salah satu potensi perekonomian nasional yang memiliki peranan yang penting dalam menumbuhkembangkan perekonomian nasional (Khairan, 2019), pada tanggal 12 Mei 2011, Bursa Efek Indonesia meluncurkan Indeks Saham Syariah Indonesia (ISSI). ISSI merupakan indikator dari kinerja pasar saham syariah di Indonesia, dimana konstituen ISSI adalah seluruh saham syariah yang tercatat di Bursa Efek Indonesia dan masuk ke dalam Daftar Efek Syariah (DES) yang diterbitkan oleh Otoritas Jasa Keuangan (OJK). Semua saham yang sesuai dengan kategori syariah masuk ke dalam ISSI tanpa ada seleksi lebih lanjut seperti Jakarta Islamic Index. Pengumuman konstituen ISSI yang dilakukan secara regular/periodik dalam dua kali satu tahun secara tidak langsung memberikan informasi kepada publik bahwa saham perusahaan yang masuk dan tetap bertahan di ISSI merupakan saham yang sesuai syariah, sedangkan saham perusahaan yang keluar dari ISSI merupakan saham yang tidak lagi sesuai syariah. Jika informasi yang terkandung pada pengumuman ISSI ini dianggap penting oleh pihak-pihak yang berkepentingan maka akan memberikan dampak dan mampu mempengaruhi harga saham.

Perkembangan pasar modal di Indonesia yang tergambar pada indikator-indikator utama pasar modal yang terus tumbuh dari tahun ke tahun mampu menjadi pendorong pertumbuhan ekonomi yang berdampak pada kegiatan investasi yang mulai meningkat. Peningkatan ini antara lain didorong oleh perkembangan pasar modal syariah. Kuatnya peran pasar modal syariah yang meningkat dalam pembentukan kapitalisasi pasar modal Indonesia mengindikasikan pasar modal syariah memiliki peran yang besar dalam hal mendorong pertumbuhan ekonomi Indonesia (Fauzan \& Suhendro, 2018). Berdasarkan data dari Otoritas Jasa Keuangan, jumlah saham syariah pada tahun 2018 adalah sebanyak 399 saham dari total 619 saham yang tercatat di bursa efek. Kondisi ini menunjukkan bahwa kepatuhan syariah mulai dijadikan sebagai bagian yang inheren dalam manajemen sebuah perusahaan. Berdasarkan data Otoritas Jasa Keuangan per januari 2020 menyatakan bahwa 64\% saham yang ada di pasar modal merupakan saham yang patuh syariah. Peningkatan saham syariah juga diikuti oleh meningkatnya jumlah investor saham syariah. Sebagaimana terlihat pada gambar berikut:

\section{Gambar 1}

Pergerakan Jumlah Investor Saham Syariah di Indonesia
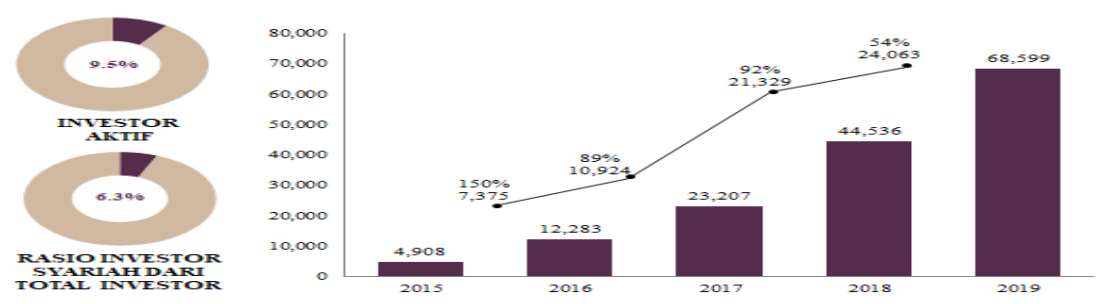

Sumber: OJK (data diolah) 
FINANCE: a Research Journal on Islamic Finance Vol.07 No. 02 Desember 2021 http//jurnal.radenfatah.ac.id/index.php/i-finance

Ellysa, Sigid dan Saiful.........Reaksi Pasar Atas Pengungkapan Kepatuhan Syariah

Pada gambar 1 terlihat bahwa jumlah investor saham syariah meningkat tajam dari waktu ke waktu. Rasio peningkatan investor saham syariah dari tahun 2015 ke 2019 mencapai $1.298 \%$. Kondisi ini menunjukkan bahwa terdapat minat investor yang tinggi terhadap surat berharga yang memenuhi aspek kepatuhan syariah.

Dalam signaling theory dijelaskan bahwa informasi publik berguna bagi para investor untuk menentukan tindakan investasi yang akan dilakukan. Signalling theory sangat erat hubungannya dengan pasar efisien bentuk setengah kuat (semi strong form) dimana harga saham bukan mencerminkan harga-harga di waktu yang lalu (Sujana, 2017), namun menyesuaikan secara cepat dengan adanya tambahan informasi, dan oleh karena itu harga saham tersebut sudah mencakupi seluruh informasi yang ada (Reilly, Frank K., Brown, 2019). Investor akan mendasarkan keputusannya pada berbagai informasi yang dimilikinya, baik informasi yang tersedia di publik maupun informasi pribadi. Informasi tersebut akan bernilai bagi investor apabila keberadaan informasi tersebut menyebabkan mereka melakukan transaksi di pasar modal. Jika informasi yang diumumkan telah diterima oleh semua pelaku pasar, maka pelaku pasar dapat menginterpretasikan dan menganalisis informasi tersebut sebagai berita baik atau berita buruk.

Informasi publik berupa informasi saham yang sesuai syariah (patuh syariah) atau tidak bukan hanya sekedar informasi publik biasa. Informasi ini merupakan informasi yang fundamental dikarenakan pengungkapan informasi terkait dengan daftar-daftar efek atau surat berharga yang bisa diinvestasikan dalam hal ini saham yang patuh syariah adalah kunci bagi investor muslim dan manajer investasi syariah, dimana portofolio investasi mereka dipilih berdasarkan pengumuman indeks syariah tersebut (Jaballah et al., 2018).

Hasil dari interpretasi informasi inilah nantinya yang akan mempengaruhi permintaan dan penawaran dari investor. Jika banyak investor berpandangan pesimis akibat berita buruk atau sinyal negatif dari informasi yang diterima, maka ia akan mengurangi jumlah pembelian dan akan menambah penawaran di pasar sehingga harga akan terdorong turun. Sebaliknya jika investor memandang optimis akibat berita baik atau sinyal positif dari informasi yang diterima, maka ia akan menambah jumlah pembelian dan akan menurunkan penawaran di pasar sehingga harga akan terdorong naik (Uhl, 2014).

Saham yang dinyatakan memenuhi standar kepatuhan syariah (sharia compliance) memiliki pengaruh yang berbeda terhadap harga saham. Di negara mayoritas muslim, investor merasa lebih bisa mendapatkan nilai tambah pada perusahaan yang masuk ke dalam indeks saham syariah dikarenakan perusahaan tersebut sesuai dengan prinsip syariah yang spesifik perihal etika keuangan dan dengan demikian dapat mendorong perilaku pembelian yang didasarkan pada kepercayaan investor (Kumar et al., 2011). Pada penelitian lain dengan tanpa memperhatikan kepercayaan yang dianut masyarakatnya, pengungkapan/pengumuman saham yang sesuai dengan standar syariah juga memberikan dampak yang positif terhadap harga saham (Alhomaidi et al., 2018). Namun, di negara mayoritas non muslim memiliki respon sebaliknya (Jaballah et al., 2018). Di sisi lain, pada penelitian yang juga mengamati reaksi atas diluncurkannya Indeks Saham Syariah Indonesia menunjukkan hasil yang berbeda, yaitu abnormal return saham hanya terjadi pada periode pengamatan (jendela peristiwa/event window) 15 hari sebelum peluncuran ISSI sedangkan pada jendela peristiwa setelah peluncuran indeks tidak ditemukan abnormal return yang positif (Yanti, 2012).

Secara umum, pada beberapa penelitian sebelumnya, ditemukan kurang lebih tiga hasil yang berbeda. Pertama, pada penelitian di negara mayoritas muslim, variabel independen berupa pengumuman kepatuhan syariah perusahaan memberikan dampak 
FINANCE: a Research Journal on Islamic Finance Vol.07 No. 02 Desember 2021 http//jurnal.radenfatah.ac.id/index.php/i-finance

Ellysa, Sigid dan Saiful.........Reaksi Pasar Atas Pengungkapan Kepatuhan Syariah

positif terhadap variabel dependen yaitu harga saham closing price yang ditunjukkan oleh nilai abnormal return yang positif, yang disimpulkan sebagai reaksi pasar yang positif. Kedua, pada penelitian yang dilakukan di Indonesia, reaksi pasar yang positif hanya terjadi untuk pengamatan dalam jangka waktu panjang saja, namun ketika penelitian dilakukan dengan jangka waktu pengamatan yang lebih pendek pasar bereaksi secara negatif terhadap variabel dependen pengumuman kepatuhan syariah. Fenomena reaksi pasar yang berbeda pada beberapa penelitian yang dilakukan di berbagai negara, dimana pengumuman kepatuhan syariah tidak selalu menyebabkan harga saham closing price meningkat, menyebabkan penelitian lanjutan dengan jangka waktu yang lebih panjang dan detail sangat diperlukan untuk mengetahui apa yang sebenarnya terjadi dan bagaimana reaksi pasar yang ditunjukkan oleh abnormal return dengan menghitung harga saham closing price atas setiap informasi kepatuhan syariah dipublikasi.

Dengan hasil penelitian ini, diharapkan investor memiliki tambahan informasi terkait dengan analisa dalam pilihan berinvestasi, terutama dalam menambah literasi dalam analisa teknikal yang membantu para investor dalam menentukan kapan harus membeli atau menjual saham yang dimiliki agar memberikan keuntungan yang ingin dicapai. Oleh karena itu, tujuan dari penelitian ini adalah untuk mengetahui bagaimana reaksi pasar atas informasi kepatuhan syariah terhadap perusahaan yang patuh syariah di Indonesia selaku negara dengan mayoritas penduduk muslim menjadi penting untuk diketahui.

Permasalahan yang akan di bahas dalam penelitian ini adalah Bagaimana reaksi pasar atas pengungkapan kepatuhan syariah terhadap perusahaan yang dinyatakan tidak patuh syariah yang tercermin pada pengumuman perubahan komposisi saham dalam penghitungan Indeks Saham Syariah Indonesia periode 2011-2019?

Berdasarkan masalah tersebut maka tujuan yang hendak dicapai dalam penelitian ini adalah untuk mengetahui reaksi pasar atas pengungkapan kepatuhan syariah terhadap perusahaan yang dinyatakan tidak patuh syariah yang tercermin pada pengumuman perubahan komposisi saham dalam penghitungan Indeks Saham Syariah Indonesia periode 2011-2019

\section{METODOLOGI PENELITIAN}

\section{Populasi dan Sampel}

Populasi dalam penelitian ini adalah seluruh perusahaan yang tercatat pada pengumuman Indeks Saham Syariah Indonesia periode 2011-2019. Dari populasi tersebut, sampel yang akan digunakan adalah sampel yang telah dipilih dengan menggunakan teknik purposive sampling dengan kriteria sebagai berikut:

1. Merupakan perusahaan yang terdapat pada lampiran pengumuman daftar Indeks Saham Syariah Indonesia periode 2011 hingga 2019

2. Memiliki nilai close price

3. Tidak terdapat corporate action pada periode estimasi, periode pengamatan dan pada hari/tanggal peristiwa (event date)

Data saham bisa saja terkontaminasi atau dimungkinkan terpengaruh oleh peristiwa lain berupa corporate action seperti perubahan jajaran pemimpin perusahaan, pengumuman laba, pembagian dividen, stock split, pengumuman akuisisi dan lain-lain selama periode pengamatan. Sehingga diperlukan penentuan kriteria yang tepat atas sampel yang akan digunakan yaitu dengan melakukan sortir data sampel yang pada periode yang sama terdapat peristiwa lain di luar pengumuman komposisi perubahan indeks saham syariah. 
FINANCE: a Research Journal on Islamic Finance Vol.07 No. 02 Desember 2021 http//jurnal.radenfatah.ac.id/index.php/i-finance

Ellysa, Sigid dan Saiful.........Reaksi Pasar Atas Pengungkapan Kepatuhan Syariah

Berdasarkan kriteria tersebut, terdapat 19 data sampel untuk saham patuh syariah dan 27 data sampel untuk saham tidak patuh syariah yang memenuhi kriteria, yaitu sebagai berikut:

Tabel 1

Pemilihan Sampel Penelitian

\begin{tabular}{lc}
\hline \multicolumn{1}{c}{ Kriteria } & Jumlah \\
\hline $\begin{array}{l}\text { Jumlah Perusahaan yang masuk ke dalam Pengumuman Perubahan Komposisi } \\
\text { Saham dalam Penghitungan ISSI setiap periode }\end{array}$ & 363 \\
\hline Jumlah Perusahaan yang tidak memiliki nilai close price & 11 \\
\hline $\begin{array}{l}\text { Jumlah Sampel yang terdapat corporate action pada periode estimasi, periode } \\
\text { pengamatan dan pada hari/tanggal peristiwa (event date) }\end{array}$ & 43 \\
\hline Total Sampel yang digunakan terhitung dari periode 2011-2019 & 309 \\
\hline
\end{tabular}

Sumber: Pengumuman ISSI (data diolah)

Berdasarkan tabel diatas dapat di artikan bahwa sampel yang sesuai dengan kriteria serta kebutuhan peneliti berjumlah 309 sampel.

Tabel 2

Sampel Terpilih

\begin{tabular}{llrrr}
\hline No & $\begin{array}{c}\text { Tanggal Peristiwa/Tanggal } \\
\text { Saham dalam Penghitungan ISSI } \\
\text { (Event Date) }\end{array}$ & Populasi & $\begin{array}{c}\text { Sampel Data yang } \\
\text { Tidak Sesuai } \\
\text { Kriteria }\end{array}$ & $\begin{array}{c}\text { Sampel } \\
\text { Data } \\
\text { Sesuai } \\
\text { Kriteria }\end{array}$ \\
\hline 1 & 07 Juni 2011 & 22 & 4 & 18 \\
\hline 2 & 06 Desember 2011 & 23 & 4 & 19 \\
\hline 3 & 30 Mei 2012 & 51 & 10 & 41 \\
\hline 4 & 30 November 2012 & 30 & 1 & 29 \\
\hline 5 & 29 Mei 2013 & 15 & 1 & 14 \\
\hline 6 & 28 November 2013 & 35 & 5 & 30 \\
\hline 7 & 26 Juni 2014 & 1 & 1 & 0 \\
\hline 8 & 22 Desember 2014 & 1 & 1 & 0 \\
\hline 9 & 28 Mei 2016 & 22 & 1 & 16 \\
\hline 10 & 27 November 2015 & 18 & 3 & 20 \\
\hline 11 & 30 Mei 2016 & 23 & 5 & 28 \\
\hline 12 & 28 November 2016 & 33 & 5 & 15 \\
\hline 13 & 30 Mei 2017 & 20 & 1 & 0 \\
\hline 14 & 04 Desember 2017 & 1 & 3 & 19 \\
\hline 15 & 30 Mei 2018 & 22 & 0 & 26 \\
\hline 16 & 28 November 2018 & 26 & 3 & 17 \\
\hline 17 & 27 Mei 2019 & 20 & $\mathbf{5 4}$ & $\mathbf{3 0 9}$ \\
\hline Sub Total & $\mathbf{3 6 3}$ & & \\
\hline
\end{tabular}

Sumber: Pengumuman ISSI (data diolah)

Dari keseluruhan 363 saham yang masuk pada kategori perusahaan patuh syariah, terdapat 309 saham yang memenuhi kriteria atau sekitar 85\% dari jumlah populasi, 54 saham sisanya dieliminasi karena tidak sesuai dengan kriteria yang dibutuhkan. Sedangkan sektor industri yang mendominasi sampel pada kategori ini adalah consumer cyclicals dengan total $17 \%$, yang diikuti oleh sektor-sektor lain sebagaimana terlihat pada gambar berikut: 
FINANCE: a Research Journal on Islamic Finance Vol.07 No. 02 Desember 2021 http//jurnal.radenfatah.ac.id/index.php/i-finance

Ellysa, Sigid dan Saiful.........Reaksi Pasar Atas Pengungkapan Kepatuhan Syariah

Gambar 3

Klasifikasi Sektor Industri Sampel

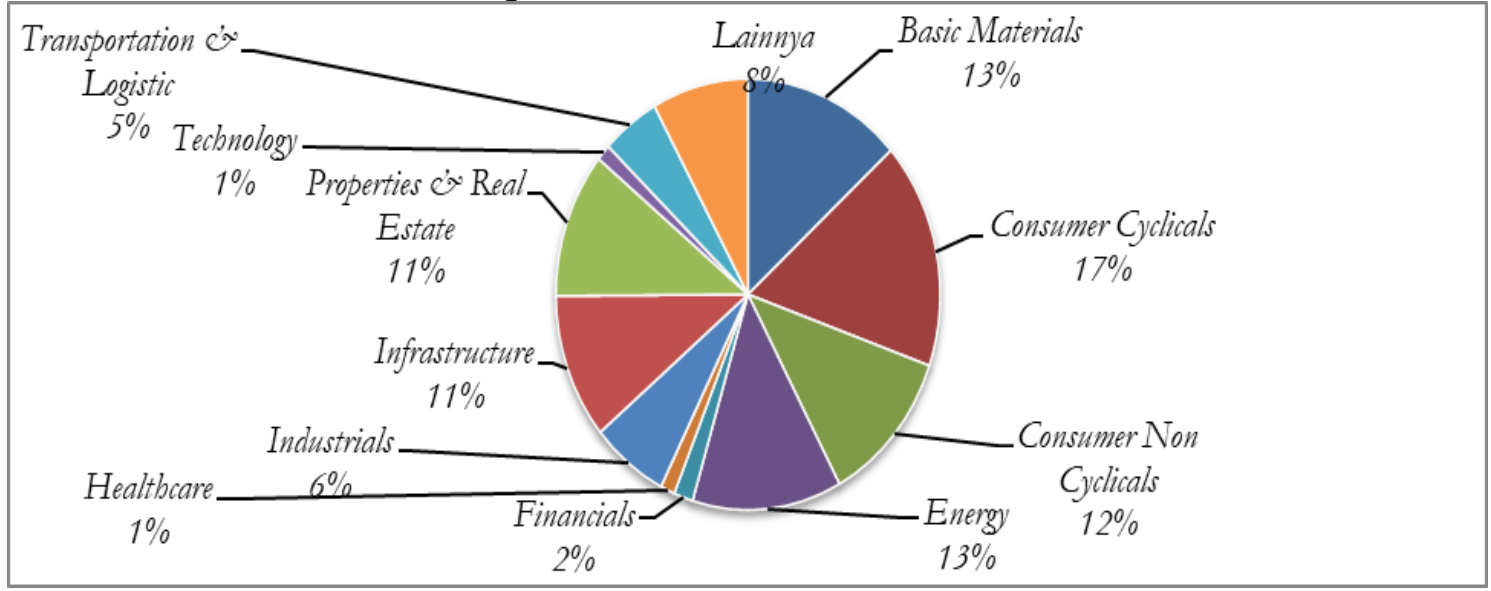

Sumber: Pengumuman ISSI (data diolah)

\section{Variabel Penelitian}

Variabel yang digunakan dalam penelitian ini terdiri dari variabel independen dan dependen meliputi:

1. Variabel Independen

Kepatuhan syariah merupakan manifestasi pemenuhan seluruh prinsip syariah dalam lembaga yang memiliki wujud karateristik, integritas dan kredibilitas di bank syariah maupun lembaga keuangan syariah nonbank. Pengungkapan kepatuhan syariah perusahaan dilihat melalui pengumuman perubahan komposisi saham dalam penghitungan Indeks Saham Syariah Indonesia periode 2011-2019.

2. Variabel Dependen

Reaksi Pasar merupakan respon yang diberikan oleh pasar atas adanya informasi tertentu yang ditunjukkan dengan adanya perubahan harga saha dari sekuritas/perusahaan bersangkutan. Harga saham yang terjadi di pasar bursa ditentukan oleh pelaku pasar, permintaan dan penawaran saham di pasar modal (Hartono, 2017). Harga saham menentukan kekayaan pemegang saham. Sedangkan harga penutupan saham sendiri adalah harga yang diminta oleh penjual atau pembeli pada saat akhir hari bursa (Sawidji, 2012). Harga saham penutupan (closing price) dijadikan sebagai variabel untuk menghitung abnormal return yang dimana bbnormal return saham digunakan sebagai tolok ukur untuk mengetahui reaksi pasar atas informasi kepatuhan syariah sepanjang tahun 2011 hingga tahun 2019. Jika pada pengumuman ISSI mengandung informasi maka pasar akan bereaksi terhadap informasi tersebut. Abnormal return saham yang positif akan terlihat apabila informasi ISSI tersebut dianggap memiliki sinyal yang positif. Sebaliknya, abnormal return saham yang negatif akan muncul apabila informasi ISSI dianggap sebagai sinyal negatif.

\section{Teknik Analisis}

Metode yang dilakukan pada event study memungkinkan peneliti bisa melihat dampak peristiwa tersebut di atas terhadap sesuatu, apakah itu return, wealth, harga saham atau lainnya.

Terdapat beberapa langkah dalam melakukan teknik analisis ini, yaitu: 
FINANCE: a Research Journal on Islamic Finance Vol.07 No. 02 Desember 2021 http//jurnal.radenfatah.ac.id/index.php/i-finance

Ellysa, Sigid dan Saiful.........Reaksi Pasar Atas Pengungkapan Kepatuhan Syariah

1. Mendefinisikan kejadian yang diminati, yaitu berupa informasi baru yang tersedia di pasar. Pada penelitian ini informasi yang digunakan adalah pengumuman daftar Indeks Saham Syariah Indonesia yang mengungkapkan saham perusahaan apa saja yang patuh dan tidak patuh syariah pada. Waktu pengumuman ini dijadikan sebagai event date.

2. Menyusun suatu teori yang memberikan alasan atau menjelaskan respon keuangan terhadap informasi baru tersebut.

3. Mengidentifikasikan kumpulan perusahaan yang mengalami kejadian tersebut dan mengindentifikasi tanggal kejadian (event date); pada tahapan ini dilakukan kriteria seleksi apakah data yang tersedia bisa dijadikan sampel penelitian

4. Memilih sebuat event window yang cocok dan justifikasi jaraknya, apabila melebihi dua hari. Dalam hal ini berarti mengidentifikasi periode dimana harga-harga saham perusahaan yang terlibat dengan kejadian tersebut akan diuji. Dalam penelitian ini, rangkaian waktu event study yang digunakan adalah seperti yang terlihat pada gambar berikut:

Gambar 4

Rangkaian Waktu Sebuah Event Study

$\underbrace{\mathrm{t}-70 \quad \mathrm{t}-21}_{\text {Periode Estimasi (Estimation Period) }} \underbrace{\mathrm{t}-5}_{\text {Jendela Peristiwa (Event Window) }}$

Sumber: Olah Peneliti, Tahun 2021

Rangkaian waktu pada gambar 4 digunakan untuk menghitung return ekspektasi. Model dalam menghitung pada penelitian ini adalah market model. Berikut adalah tahapan untuk menghitung abnormal return.

1. Return Realisasi Saham Individual dihitung selama periode estimasi yaitu selama periode 2018 dan periode peristiwa yaitu 60 hari setelah dan sebelum peristiwa dengan menggunakan rumus sebagai-berikut:

$$
\mathrm{R}_{\mathrm{it}}=\left(\mathrm{P}_{\mathrm{it}}-\mathrm{P}_{\mathrm{it}-\mathrm{l}}\right) / \mathrm{P}_{\mathrm{it}-\mathrm{l}}
$$

\section{Keterangan:}

$\mathrm{R}_{\mathrm{it}}=$ Return saham i pada periode $\mathrm{t}$

$\mathrm{P}_{\mathrm{it}}=$ Harga saham i pada periode $\mathrm{t}$

$\mathrm{P}_{\mathrm{it}-1}=$ Harga saham i pada periode $\mathrm{t}-1$

2. Return Indeks Pasar Saham dihitung selama periode 2018 yaitu 60 hari setelah dan sebelum peristiwa (event window) dengan menggunakan rumus sebagai-berikut:

$$
\mathrm{RETPBN}_{\mathrm{t}}=\left(\mathrm{IHSG}_{\mathrm{t}}-\mathrm{IHSG}_{\mathrm{t}-1}\right) / \mathrm{IHSG}_{\mathrm{t}-1}
$$
Keterangan:
RETPBN $_{t}=$ Return pasar hari ke $t$
IHSG $_{\mathrm{t}}=$ indeks pasar hari ke $\mathrm{t}$
IHSG $_{\mathrm{t}-1} \quad=$ indeks pasar hari ke $\mathrm{t}-1$

3. Return Ekspektasi Saham dihitung dengan menggunakan market model yang dilakukan dengan dua tahap yaitu, pertama membentuk model ekspektasi dan diperoleh persamaan sebagai berikut:

$$
E\left(\text { RETH }_{i t}\right)=\alpha+\beta \cdot \text { RETPBN }_{t}
$$


FINANCE: a Research Journal on Islamic Finance Vol.07 No. 02 Desember 2021 http//jurnal.radenfatah.ac.id/index.php/i-finance

Ellysa, Sigid dan Saiful.........Reaksi Pasar Atas Pengungkapan Kepatuhan Syariah

Keterangan:

$\mathrm{E}\left(\mathrm{RETH}_{\mathrm{it}}\right)=$ return ekspektasi saham i pada periode $\mathrm{t}$

$\alpha \quad=$ intercept saham ke i

$\beta=$ beta saham ke I

RETPBNt $=$ return indeks pasar pada periode $\mathrm{t}$

4. Abnormal return dihitung dengan menggunakan rumus sebagai berikut:

ARPST $=$ RETH $_{\text {it }}-$ E $\left(\right.$ RETH $\left._{\text {it }}\right)$

Keterangan:

ARPST = abnormal return

$\mathrm{RETH}_{\mathrm{it}} \quad=$ actual return

$\mathrm{E}\left(\mathrm{RETH}_{\mathrm{it}}\right)=$ return ekspektasi

5. Cumulative abnormal return setiap saham dihitung dengan menggunakan rumus berikut:

$$
\mathrm{CARPST}_{\text {it }}=\sum \mathrm{ARPST}_{\text {it }}
$$

Keterangan:

CARPST $_{\text {it }}=$ cumulative abnormal return

$\sum \mathrm{ARPST}_{\mathrm{it}}=$ total abnormal return

6. Average abnormal return setiap saham dihitung dengan menggunakan rumus berikut:

$$
\mathrm{AARPST}_{\text {it }}=\mathrm{CARPST}_{\text {it }} / \mathrm{n}
$$

Keterangan:

AARPST $_{\text {it }}=$ average abnormal return

CARPST $_{\text {it }}=$ cumulative abnormal return

$\mathrm{n} \quad=$ total saham yang dijadikan sampel

Data yang terdistribusi normal diharapkan dapat mewakili nilai populasi sehingga sampel yang dijadikan penaksir dapat mewakili populasi ketika ditarik kesimpulan tentang nilai populasi sebenarnya (Gujarati, 2012). Uji normalitas yang digunakan dalam penelitian ini adalah uji Skewness-Kurtosis yang diperkenalkan oleh D'Agostino dan Belanger pada tahun 1990. Uji Skewness-Kurtosis digunakan karena uji ini akan tetap mendeteksi ketidaknormalan pada jumlah sampel berapapun, baik jumlah kecil maupun besar. Jika pada data normal uji signifikansi bisa dilakukan dengan menggunakan one sample t-test, maka pada data tidak normal uji ini tidak tepat untuk dilakukan. Salah satu masalah dalam tes statistik untuk abnormal return harga saham adalah data yang tidak terdistribusi normal. Penelitian ini menggunakan uji non parametric lainnya yaitu Wilcoxon yang menampilkan uji signed-rank oleh Wilcoxon (Pacicco et al., 2018).

\section{HASIL DAN PEMBAHASAN}

\section{HASIL PENELITIAN}

Data sampel yang digunakan adalah sebanyak 309 saham yang patuh syariah sepanjang 2011-2019. Tabel berikut berisi deskripsi data return saham yang digunakan dalam penelitian ini, yang terdiri dari data saham perusahaan yang patuh syariah.

\section{Tabel 3}

Deskripsi Data Return Saham

\begin{tabular}{crrrrr}
\hline Variable & Obs & \multicolumn{1}{l}{ Mean } & \multicolumn{1}{c}{ Std. Dev. } & \multicolumn{1}{l}{ Min } & \multicolumn{1}{l}{ Max } \\
\hline sps & 1271 & .00121 & .0192331 & -.0592923 & .4438485 \\
\hline ihsg & 1271 & -.00009 & .0109369 & -.0888037 & .0475858 \\
\hline
\end{tabular}

Sumber: Data Primer, diolah tahun 2021 
FINANCE: a Research Journal on Islamic Finance Vol.07 No. 02 Desember 2021 http//jurnal.radenfatah.ac.id/index.php/i-finance

Ellysa, Sigid dan Saiful........Reaksi Pasar Atas Pengungkapan Kepatuhan Syariah

Berdasarkan tabel 3 diperoleh data bahwa nilai return saham tertinggi pada data sampel saham patuh syariah adalah 0,4438485, return terendah adalah $-0,0592923$, dan standar deviasinya adalah 0,0192331. Sedangkan IHSG, nilai return saham tertinggi adalah 0,0475858, return terendah $-0,0888037$, dan standar deviasinya adalah 0,0109369 .

\section{Tabel 4}

\section{Uji Normalitas}

Shapiro-Wilk W test for normal data

\begin{tabular}{cccrrr}
\hline Variable & Obs & w & v & \multicolumn{1}{c}{ z } & \multicolumn{1}{c}{ Prob $>\mathbf{z}$} \\
\hline sps & 1271 & 0.42138 & 454.063 & 15.298 & 0.00000 \\
\hline ihsg & 1271 & 0.93846 & 48.296 & 9.695 & 0.00000 \\
\hline
\end{tabular}

Sumber: Data Primer, diolah tahun 2021

Pada tabel 4, terlihat bahwa pada kolom Prob>chi2 menunjukkan nilai 0,0000 untuk data sampel pada kategori saham patuh syariah dan IHSG. Data dikatakan normal jika nilai prob $>0,05$. Berdasarkan data pada tabel uji normalitas, maka data sampel saham patuh syariah dan tidak patuh syariah tidak berdistribusi normal. Sehingga, uji signifikansi yang digunakan menggunakan uji non parametric yaitu uji signed-rank Wilcoxon.

Tabel 5

Uji Signifikansi dan Nilai Cumulative Average Abnormal Return (CAAR) Perusahaan Patuh Syariah

CAAR Saham Perusahaan Patuh Syariah

\begin{tabular}{|c|c|c|c|c|c|c|c|}
\hline $\mathrm{t}$ & $(-5,0)$ & $(-3,0)$ & $(-1,0)$ & $(0,0)$ & $(0,1)$ & $(0,3)$ & $(0,5)$ \\
\hline 07 Juni 2011 & $\begin{array}{c}1.875 \% \\
* * *\end{array}$ & $\begin{array}{c}0.555 \% \\
* * *\end{array}$ & $\begin{array}{c}1.319 \% \\
* * *\end{array}$ & $\begin{array}{c}1.492 \% \\
* * *\end{array}$ & $\begin{array}{c}1.044 \% \\
* * *\end{array}$ & $\begin{array}{c}-1.020 \% \\
* * *\end{array}$ & $\begin{array}{c}-2.139 \% \\
* * *\end{array}$ \\
\hline 06 Des 2011 & $\begin{array}{c}1.447 \% \\
* * *\end{array}$ & $\begin{array}{c}2.804 \% \\
* * *\end{array}$ & $\begin{array}{c}1.436 \% \\
* * *\end{array}$ & $\begin{array}{c}1.254 \% \\
* * *\end{array}$ & $\begin{array}{c}2.971 \% \\
* * *\end{array}$ & $\begin{array}{c}2.271 \% \\
* * *\end{array}$ & $\begin{array}{c}1.643 \% \\
* * *\end{array}$ \\
\hline 30 Mei 2012 & $\begin{array}{c}-2.898 \% \\
* * *\end{array}$ & $\begin{array}{c}-1.822 \% \\
*\end{array}$ & $-1.033 \%$ & $-1.066 \%$ & $-2.119 \%$ & $\begin{array}{c}-4.818 \% \\
*\end{array}$ & $\begin{array}{c}-1.713 \% \\
* * *\end{array}$ \\
\hline 30 Nov 12 & $\begin{array}{c}-0.854 \% \\
* * *\end{array}$ & $\begin{array}{c}-0.665 \% \\
* * *\end{array}$ & $\begin{array}{c}-0.311 \% \\
* * *\end{array}$ & $\begin{array}{c}-0.109 \% \\
* * *\end{array}$ & $\begin{array}{c}-0.328 \% \\
* * *\end{array}$ & $\begin{array}{c}0.558 \% \\
* * *\end{array}$ & $\begin{array}{c}0.826 \% \\
* * *\end{array}$ \\
\hline 29 Mei 2013 & $\begin{array}{c}-2.535 \% \\
* * *\end{array}$ & $\begin{array}{c}0.371 \% \\
* * *\end{array}$ & $\begin{array}{c}-1.275 \% \\
* * *\end{array}$ & $\begin{array}{c}-0.427 \% \\
* * *\end{array}$ & $\begin{array}{c}-0.278 \% \\
* * *\end{array}$ & $\begin{array}{c}-1.175 \% \\
* * *\end{array}$ & $\begin{array}{c}1.426 \% \\
* * *\end{array}$ \\
\hline 28 Nov 13 & $\begin{array}{c}1.469 \% \\
* * *\end{array}$ & $\begin{array}{c}1.674 \% \\
* * *\end{array}$ & $\begin{array}{c}0.680 \% \\
* * *\end{array}$ & $\begin{array}{c}0.240 \% \\
* * *\end{array}$ & $\begin{array}{c}0.747 \% \\
* * *\end{array}$ & $\begin{array}{c}0.514 \% \\
* * *\end{array}$ & $\begin{array}{c}2.156 \% \\
* * *\end{array}$ \\
\hline 28 Mei 2015 & $\begin{array}{c}3.640 \% \\
* * *\end{array}$ & $\begin{array}{c}2.816 \% \\
* * *\end{array}$ & $\begin{array}{c}1.737 \% \\
* * *\end{array}$ & $\begin{array}{c}0.346 \% \\
* * *\end{array}$ & $\begin{array}{c}0.091 \% \\
* * *\end{array}$ & $\begin{array}{c}1.157 \% \\
* * *\end{array}$ & $\begin{array}{c}3.293 \% \\
* * *\end{array}$ \\
\hline 27 Nov 15 & $\begin{array}{c}-2.057 \% \\
* * *\end{array}$ & $\begin{array}{c}-0.035 \% \\
* * *\end{array}$ & $\begin{array}{c}0.512 \% \\
* * *\end{array}$ & $\begin{array}{c}-0.296 \% \\
* * *\end{array}$ & $\begin{array}{c}0.938 \% \\
* * *\end{array}$ & $\begin{array}{c}-0.130 \% \\
* * *\end{array}$ & $\begin{array}{c}0.665 \% \\
* * *\end{array}$ \\
\hline 30 Mei 2016 & $\begin{array}{c}-0.463 \% \\
* * *\end{array}$ & $\begin{array}{c}0.018 \% \\
* * *\end{array}$ & $\begin{array}{c}-0.610 \% \\
* * *\end{array}$ & $\begin{array}{c}-1.006 \% \\
* * *\end{array}$ & $\begin{array}{c}-0.606 \% \\
* * *\end{array}$ & $\begin{array}{c}-1.591 \% \\
* * *\end{array}$ & $\begin{array}{c}0.004 \% \\
* * *\end{array}$ \\
\hline 28 Nov 16 & $\begin{array}{c}5.075 \% \\
* * *\end{array}$ & $\begin{array}{c}2.728 \% \\
* * *\end{array}$ & $\begin{array}{c}2.365 \% \\
* * *\end{array}$ & $\begin{array}{c}-0.218 \% \\
* * *\end{array}$ & $\begin{array}{l}0.151 \% \\
* * *\end{array}$ & $\begin{array}{c}0.778 \% \\
* * *\end{array}$ & $\begin{array}{c}3.798 \% \\
* * *\end{array}$ \\
\hline 30 Mei 2017 & $\begin{array}{c}2.393 \% \\
* * *\end{array}$ & $\begin{array}{c}1.760 \% \\
* * *\end{array}$ & $\begin{array}{c}1.048 \% \\
* * *\end{array}$ & $\begin{array}{c}0.862 \% \\
* * *\end{array}$ & $\begin{array}{c}0.610 \% \\
* * *\end{array}$ & $\begin{array}{c}1.004 \% \\
* * *\end{array}$ & $\begin{array}{c}-0.412 \% \\
* * *\end{array}$ \\
\hline 30 Mei 2018 & $\begin{array}{c}4.078 \% \\
* * *\end{array}$ & $\begin{array}{c}2.082 \% \\
* * *\end{array}$ & $\begin{array}{c}-0.514 \% \\
* * *\end{array}$ & $\begin{array}{c}-1.164 \% \\
* * *\end{array}$ & $\begin{array}{c}-0.409 \% \\
* * *\end{array}$ & $\begin{array}{c}-3.376 \% \\
* * *\end{array}$ & $\begin{array}{c}-2.326 \% \\
* * *\end{array}$ \\
\hline 28 Nov 18 & $\begin{array}{c}-2.782 \% \\
* * *\end{array}$ & $\begin{array}{c}-1.427 \% \\
* * *\end{array}$ & $\begin{array}{c}0.816 \% \\
* * *\end{array}$ & $\begin{array}{c}0.969 \% \\
* * *\end{array}$ & $\begin{array}{c}-1.615 \% \\
* * *\end{array}$ & $\begin{array}{c}-0.139 \% \\
* * *\end{array}$ & $\begin{array}{c}0.677 \% \\
* * *\end{array}$ \\
\hline 27 Mei 2019 & $\begin{array}{c}-0.509 \% \\
* * *\end{array}$ & $\begin{array}{c}0.122 \% \\
* * *\end{array}$ & $\begin{array}{c}0.114 \% \\
\text { *** }\end{array}$ & $\begin{array}{c}-0.299 \% \\
* * *\end{array}$ & $\begin{array}{c}0.366 \% \\
* * *\end{array}$ & $\begin{array}{c}1.791 \% \\
* * *\end{array}$ & $\begin{array}{c}1.991 \% \\
* * *\end{array}$ \\
\hline
\end{tabular}

Sumber: Data Primer, diolah tahun 2021 
FINANCE: a Research Journal on Islamic Finance Vol.07 No. 02 Desember 2021 http//jurnal.radenfatah.ac.id/index.php/i-finance

Ellysa, Sigid dan Saiful.........Reaksi Pasar Atas Pengungkapan Kepatuhan Syariah

Tabel 5 menampilkan uji signifikansi terhadap abnormal return yang digunakan untuk pengujian hipotesis reaksi pasar terhadap perusahaan patuh syariah dengan menggunakan uji wilxocon. Data pada tabel menunjukkan bahwa abnormal return pada setiap pengujian didominasi oleh taraf signikansi $(\alpha)$ yang berada pada level $1 \%$, kecuali pada pengujian tanggal 30 Mei 2012 pada jendela peristiwa $(-1,0),(0,0)$ dan $(0,1)$ menunjukkan abnormal return yang tidak signifikan. Sehingga dengan taraf signifikansi $(\alpha)$ didominasi pada level $1 \%$ yang diartikan bahwa tingkat kesalahan dalam pengambilan keputusan saat pengujian hipotesis berada pada level terendah yaitu 1\% sehingga bisa digunakan dalam mendukung pengambilan keputusan dalan pengujian hipotesis dengan tingkat kepercayaan sebesar $99 \%$.

Berdasarkan 14 pengujian reaksi pasar atas pengungkapan kepatuhan syariah pada pengumuman ISSI terhadap perusahaan yang patuh syariah, maka didapat hasil sebagaimana dirangkum pada tabel berikut:

\section{Tabel 6}

\section{Hasil Uji Hipotesis Saham Perusahaan Patuh Syariah}

\begin{tabular}{|c|c|c|c|}
\hline \multirow[t]{2}{*}{ No } & \multirow[t]{2}{*}{$\begin{array}{l}\text { Tanggal Peristiwa/ Tanggal } \\
\text { Pengumuman Perubahan } \\
\text { Komposisi Saham Dalam } \\
\text { Penghitungan ISSI } \\
\text { (Event Date) }\end{array}$} & \multicolumn{2}{|c|}{$\begin{array}{c}\text { Hipotesis } 1(\mathrm{H} 1) \text { : terdapat reaksi pasar yang positif atas } \\
\text { pengungkapan kepatuhan syariah terhadap perusahaan } \\
\text { yang dinyatakan patuh syariah berdasarkan pada } \\
\text { pengumuman daftar Indeks Saham Syariah Indonesia } \\
\text { pada periode 2011-2019 }\end{array}$} \\
\hline & & Hipotesis Diterima & Hipotesis Ditolak \\
\hline 1 & 07 Juni 2011 & 1 & \\
\hline 2 & 06 Desember 2011 & 1 & \\
\hline 3 & 30 Mei 2012 & & 1 \\
\hline 4 & 30 November 2012 & 1 & \\
\hline 5 & 29 Mei 2013 & 1 & \\
\hline 6 & 28 November 2013 & 1 & \\
\hline 7 & 26 Juni 2014 & & \\
\hline 8 & 22 Desember 2014 & & \\
\hline 9 & 28 Mei 2016 & 1 & \\
\hline 10 & 27 November 2015 & 1 & \\
\hline 11 & 30 Mei 2016 & 1 & \\
\hline 12 & 28 November 2016 & 1 & \\
\hline 13 & 30 Mei 2017 & 1 & \\
\hline 14 & 04 Desember 2017 & & \\
\hline 15 & 30 Mei 2018 & & 1 \\
\hline 16 & 28 November 2018 & 1 & \\
\hline 17 & 27 Mei 2019 & 1 & \\
\hline Tot & & 12 & 2 \\
\hline
\end{tabular}

Sumber: Data Primer, diolah tahun 2021

Berdasarkan tabel 6, bisa dilihat bahwa 12 dari 14 pengujian (atau sekitar 86\%) yang diuji menerima $H_{1}$, yaitu terdapat reaksi pasar yang positif terhadap perusahaan yang memenuhi aspek kepatuhan syariah sehingga masuk ke dalam indeks syariah. Adanya reaksi positif yang terjadi dimungkinkan karena para investor melakukan pembelian saham-saham 
FINANCE: a Research Journal on Islamic Finance Vol.07 No. 02 Desember 2021

http//jurnal.radenfatah.ac.id/index.php/i-finance

Ellysa, Sigid dan Saiful.........Reaksi Pasar Atas Pengungkapan Kepatuhan Syariah

patuh syariah tersebut, dimana jika kita kaitkan dengan mayoritas penduduk Indonesia beragama Islam, maka peningkatan pembelian saham patuh syariah bisa jadi disebabkan oleh perilaku pembelian yang berdasarkan keyakinan ( Kumar et al., 2011).

\section{PEMBAHASAN}

\section{Reaksi Pasar terhadap Saham Perusahaan yang Dinyatakan Patuh Syariah}

Pengujian dan analisa hipotesis $1\left(\mathrm{H}_{1}\right)$ yaitu terdapat reaksi pasar yang positif atas pengungkapan kepatuhan syariah terhadap perusahaan yang dinyatakan patuh syariah berdasarkan pada pengumuman perubahan komposisi saham dalam penghitungan Indeks Saham Syariah Indonesia periode 2011-2019 akan dilakukan pada sub bab ini. Terdapat sebanyak empat belas pengumuman perubahan komposisi saham dalam penghitungan ISSI pada kategori perusahaan yang patuh syariah, yang masing-masing hipotesis akan diuji secara terpisah dalam setiap tanggal peristiwa (tanggal pengumuman perubahan komposisi saham dalam penghitungan ISSI). Visusalisasi dalam bentuk gambar digunakan untuk melihat abnormal return yang lebih jelas dan mudah. Diawali dengan tampilan gambar abnormal return pada waktu sekitar pengumuman perubahan komposisi saham dalam penghitungan ISSI tanggal 7 Juni 2011 yang merupakan review pertama kalinya setelah Indeks Saham Syariah Indonesia (selanjutnya disingkat ISSI) diluncurkan.

Nilai akumulasi dari abnormal return yang positif dan signifikan hanya terjadi pada $(0,1)$ atau 1 hari setelah pengumuman ISSI. Dimana pada hari-hari setelahnya, akumulasi abnormal return menunjukkan nilai negatif yang signifikan. Informasi saham-saham yang masuk daftar ISSI dikarenakan patuh syariah dianggap sebagai berita baik, dimana kondisi ini mencerminkan bahwa pasar bereaksi positif meskipun hanya pada satu hari setelah kepatuhan syariah perusahaan dipublikasi. Adanya dugaan bahwa pada satu hari setelah pengungkapan kepatuhan syariah, para investor masih melakukan pembelian saham-saham patuh syariah yang menyebabkan abnormal return masih bernilai positif dan signifikan. Sehingga pengujian pada pengumuman ISSI tanggal 7 Juni 2011, $\mathrm{H}_{1}$ diterima, yaitu pasar bereaksi positif terhadap perusahaan yang masuk kategori patuh syariah dan masuk ke dalam daftar ISSI.

Abnormal return yang positif dan signifikan terlihat naik turun sepanjang jendela peristiwa. Mudah untuk simpulkan bahwa investor masih melakukan pembelian terhadap saham-saham yang dinyatakan memenuhi aspek kepatuhan syariah dan masuk ke dalam daftar ISSI, meskipun adanya tren akumulasi abnormal return yang menurun. Oleh karena itu, pada pengujian pengumuman ISSI tanggal 6 Desember 2011, $\mathrm{H}_{1}$ diterima yaitu pasar bereaksi positif terhadap saham perusahaan yang patuh syariah.

Abnormal return pada pengujian pengumuman ISSI tanggal 30 Mei 2012 menunjukkan pergerakan yang sebaliknya, dimana menunjukkan tren nilai negatif sepanjang jendela peristiwa, sehingga $\mathrm{H}_{1}$ ditolak yaitu adanya reaksi pasar yang negatif terhadap perusahaan yang dinyatakan patuh syariah dan masuk ke dalam daftar ISSI. Kondisi ini menunjukkan keadaan yang berkebalikan dari teori-teori dan penelitian-penelitian sebelumnya yang telah ada, namun tidak sepenuhnya menjadi tidak valid dan menjadi bukti penolakan teori.

Ada dua kondisi yang memungkinkan bahwa abnormal return yang positif tidak tampak setelah saham perusahaan yang patuh syariah dipublikasi. Kondisi pertama adalah adanya kemungkinan informasi yang telah diketahui lebih awal oleh sebagian investor. Seperti yang diketahui, dasar OJK dalam membuat daftar ISSI adalah daftar efek syariah atau yang dikenal dengan DES. Pengumuman DES pada dasarnya dilakukan sebelum ISSI, 
FINANCE: a Research Journal on Islamic Finance Vol.07 No. 02 Desember 2021 http//jurnal.radenfatah.ac.id/index.php/i-finance

Ellysa, Sigid dan Saiful.........Reaksi Pasar Atas Pengungkapan Kepatuhan Syariah

sehingga adanya kemungkinan investor telah memilah sendiri efek-efek mana yang masuk dalam kategori syariah pada DES. Hal ini kemudian menyiratkan bahwa antisipasi atas pengumuman perubahan komposisi dalam penghitungan ISSI telah dilakukan lebih awal oleh para investor (Yanti, 2012). Untuk memvalidasi asumsi ini, perlu dilakukan pengamatan reaksi dalam jangka waktu yang lebih panjang dan mendekati tanggal DES dipublikasi. Kondisi kedua ditunjukkan oleh abnormal return yang tidak signifikan yang ditandai dengan abnormal return yang diblok kuning. Adanya kemungkinan bahwa ada peristiwa lain yang terjadi pada sekitar tanggal daftar ISSI dipublikasi, sehingga menyebabkan aspek kepatuhan syariah bukan menjadi informasi utama para investor untuk melakukan pembelian terhadap saham-saham yang memenuhi aspek syariah. Abnormal return yang tidak signifikan juga terjadi pada perusahaan yang tidak patuh syariah, sehingga bisa disimpulkan bahwa secara makro ada peristiwa lain yang juga terjadi pada tanggal atau pada sekitar tanggal daftar ISSI diumumkan.

Selanjutnya pengujian pengumuman ISSI tanggal 30 November 2012, pada saat ISSI belum mengumumkan saham yang masuk dan keluar pada indeks tersebut, abnormal return terlihat negatif dan signifikan dengan tren yang meningkat naik menuju hari pengumuman. Akumulasi abnormal return positif dan signifikan baru terjadi pada hari ketiga dan kelima yang tunjukkan oleh jendela peristiwa $(0,3)$ dan $(0,5)$. Kondisi ini menunjukkan bahwa informasi perusahaan yang memenuhi aspek kepatuhan syariah dianggap sebagai sinyal positif oleh para investor sehingga adanya pembelian terhadap saham-saham tersebut. Oleh karena itu, $\mathrm{H}_{1}$ diterima yaitu adanya reaksi pasar yang positif terhadap perusahaan yang memenuhi aspek kepatuhan syariah dan masuk ke dalam daftar ISSI.

Pada pengujian 29 Mei 2013 menunjukkan abnormal return yang didominasi oleh nilai negatif dan signifikan hampir di sepanjang jendela peristiwa. Akumulasi abnormal return yang positif dan signifikan baru terjadi pada hari kelima setelah informasi terkait perusahaan yang memenuhi aspek kepatuhan syariah dipublikasi pada pengumuman perubahan komposisi dalam penghitungan ISSI. Akumulasi abnormal return sebesar 1,426\% menunjukkan bahwa terdapat pembelian yang dilakukan oleh para investor pada sahamsaham patuh syariah tersebut, dimana pengumuman perubahan komposisi dalam penghitungan ISSI dianggap sebagai sinyal positif. Oleh karena itu, pada pengujian pengumuman ISSI tanggal 29 Mei 2013, $\mathrm{H}_{1}$ diterima, yaitu terdapat reaksi pasar yang positif terhadap perusahaan yang dinyatakan patuh syariah dan masuk ke dalam daftar ISSI.

Abnormal return yang positif dan signifikan terlihat sepanjang jendela peristiwa pada gambar di atas. Kondisi ini mencerminkan bahwa investor masih melakukan pembelian terhadap saham-saham yang patuh syariah, dimana akumulasi abnormal return tertinggi terdapat pada hari kelima setelah pengumuman perubahan komposisi dalam penghitungan ISSI dilakukan. Oleh karena itu, berdasarkan abnormal return di atas, maka terdapat reaksi pasar yang positif pada pengujian pengumuman ISSI tanggal 28 November 2013, sehingga $\mathrm{H}_{1}$ diterima.

Sama seperti pada pengujian sebelumnya, kali ini abnormal return yang positif dan signifikan terlihat sepanjang jendela peristiwa, dengan tren yang kembali naik setelah informasi perusahaan yang memenuhi aspek kepatuhan syariah dipublikasi. Oleh karena itu, maka pada pengujian pengumuman ISSI tanggal 28 Mei 2015, $\mathrm{H}_{1}$ diterima dimana adanya reaksi pasar yang positif terhadap perusahaan yang dinyatakan patuh syariah dan masuk ke dalam daftar ISSI, yang dianggap sebagai sinyal baik oleh para investor.

Abnormal return yang negatif, positif dan signifikan tampak pada pengujian 27 November 15. Abnormal return positif tampak pada jendela peristiwa $(0,1)$ dan $(0,5)$ yaitu satu 
FINANCE: a Research Journal on Islamic Finance Vol.07 No. 02 Desember 2021 http//jurnal.radenfatah.ac.id/index.php/i-finance

Ellysa, Sigid dan Saiful.........Reaksi Pasar Atas Pengungkapan Kepatuhan Syariah

hari dan lima hari setelah aspek kepatuhan perusahaan diungkap ke publik pada pengumuman perubahan komposisi dalam penghitungan ISSI. Abnormal return yang positif signifikan pada satu hari setelah pengumuman perubahan komposisi dalam penghitungan ISSI mencerminkan bahwa para investor melakukan pembelian terhadap saham perusahan yang patuh syariah. Sedangkan akumulasi abnormal return yang negatif pada dua hari setelah pengumuman perubahan komposisi dalam penghitungan ISSI dimungkinkan terjadi karena para investor trader yang mencari keuntungan melalui capital gain menjual saham-saham patuh syariah yang dimiliki di saat harga naik dihari berikutnya. Namun, akumulasi abnormal return di lima hari setelah pengumuman perubahan komposisi dalam penghitungan ISSI yang terlihat pada jendela peristiwa $(0,5)$ kembali positif dan signifikan. Kondisi ini kemudian bisa disimpulkan bahwa informasi perusahaan yang memenuhi aspek kepatuhan syariah masih diartikan sebagai sinyal positif. oleh karena itu, $\mathrm{H}_{1}$ diterima yaitu terdapat reaksi pasar yang positif pada perusahaan yang patuh syariah dan masuk dalam daftar ISSI.

Pada pengujian 30 Mei 2016 menunjukkan abnormal return negatif dan signifikan mendominasi sepanjang jendela peristiwa. Akumulasi abnormal return positif dan signifikan terjadi pada hari kelima setelah pengumuman perubahan komposisi dalam penghitungan ISSI dipublikasi, yaitu sebesar $0,004 \%$. Situasi ini menunjukkan bahwa pembelian saham yang patuh syariah baru terjadi pada hari tersebut. Sehingga $\mathrm{H}_{1}$ diterima, yaitu terdapat reaksi pasar yang positif terhadap perusahaan yang memenuhi aspek kepatuhan syariah dan masuk ke dalam daftar ISSI.

Pengujian pada 28 November 16, abnormal return yang negatif dan signifikan hanya terjadi pada hari perusahaan yang memenuhi aspek kepatuhan syariah dipublikasi dimana tren penurunan nilai akumulasi abnormal return terjadi sejak hari kelima sebelum tanggal peristiwa ( $\mathrm{t} 0$ ). Namun kemudian pada satu hari setelahnya, saham perusahaan patuh syariah mulai menunjukkan abnormal return yang positif dan signifikan pada hari-hari setelahnya. Kondisi ini mencerminkan bahwa adanya pembelian saham patuh syariah oleh para investor, dimana informasi ini dianggap sebagai sinyal perusahaan. Oleh karena itu, berdasarkan tampilan abnormal return maka $\mathrm{H}_{1}$ diterima, yaitu terdapat reaksi pasar yang positif terhadap perusahaan yang dinyatakan patuh syariah dan disertakan dalam daftar terbaru ISSI.

Selanjutnya adalah pengujian pengumuman ISSI tanggal 30 Mei 2017, yang merupakan pengumuman perubahan komposisi dalam penghitungan ISSI ke 11 kalinya semenjak indeks ini diluncurkan menunjukkan abnormal return yang positif dan signifikan terlihat sepanjang jendela peristiwa hingga pada $(0,3)$. Hal ini menunjukkan bahwa pasar masih beraksi positif pada rentang waktu 1-3 hari setelah pengumuman perubahan komposisi dalam penghitungan ISSI, dimana pengumuman perubahan komposisi dalam penghitungan ISSI yan berisi informasi perusahaan yang memenuhi aspek kepatuhan syariah termuat di dalamnya dianggap sebagai sinyal positif. Sehingga, $\mathrm{H}_{1}$ diterima, yaitu adanya reaksi positif pasar terhadap perusahaan yang patuh syariah dan masuk ke dalam daftar ISSI.

Hal yang mengejutkan kembali terlihat pada pergerakan abnormal return pada pengujian pengumuman ISSI tanggal 30 Mei 2018, dimana penurunan abnormal return yang terus-menerus sejak sebelum pengumuman perubahan komposisi dalam penghitungan ISSI dilakukan terus terjadi bahkan hingga ke titik abnormal return yang negatif. Abnormal return yang positif dan signifikan hanya terjadi pada 5-3 hari sebelum pengumuman perubahan komposisi dalam penghitungan ISSI dipublikasi, pada hari-hari setelahnya abnormal return memiliki tren menurun. Kondisi ini mencerminkan bahwa pengumuman perubahan 
FINANCE: a Research Journal on Islamic Finance Vol.07 No. 02 Desember 2021 http//jurnal.radenfatah.ac.id/index.php/i-finance

Ellysa, Sigid dan Saiful.........Reaksi Pasar Atas Pengungkapan Kepatuhan Syariah

komposisi dalam penghitungan ISSI yang merupakan publikasi terhadap perusahaan yang memenuhi aspek syariah tidak membuat para investor tergerak untuk melakukan pembelian saham-saham perusahaan patuh syariah tersebut dalam pengamatan jangka pendek. Informasi tersebut tidak dianggap sebagai informasi yang mumpuni sebagai alasan pembelian saham-saham tersebut. Adanya ketakutan akan kondisi siklus 10 tahunan krisis ekonomi global bisa jadi menjadi salah satu penyebab informasi ini tidak begitu diindahkan oleh para investor pada Mei 2018. Oleh karena itu, berdasarkan kondisi ini, maka $\mathrm{H}_{1}$ ditolak yaitu tidak terdapat reaksi pasar yang positif terhadap saham perusahaan yang patuh syariah dan masuk ke dalam daftar ISSI.

Pada pengujian 28 November 18, abnormal return pada 5 hari sebelum pengumuman perubahan komposisi dalam penghitungan ISSI berada pada posisi negatif dan signifikan, yang kemudian merangkak naik menjelang hari pengumuman perubahan komposisi dalam penghitungan ISSI. Abnormal return yang turun di satu hari setelah pengumuman perubahan komposisi dalam penghitungan ISSI menunjukkan adanya penjualan saham-saham yang patuh syariah oleh investor trader yang mendapatkan keuntungan karena fluktuasi harga. Abnormal return perlahan-lahan naik pada posisi nilai positif pada hari kelima setelah pengumuman. Kondisi ini sudah cukup bisa sebagai bahan dalam pengambilan kesimpulan bahwa meskipun perlahan-lahan, informasi ini disikapi positif oleh pasar, meskipun dengan cara berbeda (tergantung jenis investor). Oleh karena itu, $\mathrm{H}_{1}$ diterima, dimana terdapat reaksi positif oleh pasar terhadap perusahaan yang dinyatakan patuh syariah dan masuk ke dalam daftar ISSI.

Selanjutnya adalah pengujian pengumuman ISSI tanggal 27 Mei 2019, yang merupakan pengujian terakhir dalam penelitian ini. Hasil menunjukkan tren peningkatan abnormal return setelah pengumuman perubahan komposisi dalam penghitungan ISSI dipublikasi. Akumulasi average abnormal return yang positif dan signifikan setelah pengumuman perubahan komposisi dalam penghitungan ISSI dipublikasi yaitu pada jendela peristiwa $(0,1),(0,3)$ dan $(0,5)$ ditunjukkan oleh tabel 4 . Kondisi ini tentu mencerminkan bahwa informasi yang terkandung pada pengumuman perubahan komposisi dalam penghitungan ISSI dianggap sebagai sinyal positif oleh para investor, sehingga terjadi pembelian saham-saham perusahaan tersebut. Oleh karena itu, pada pengujian pengumuman ISSI kali ini, $\mathrm{H}_{1}$ diterima, yaitu terdapat reaksi pasar yang positif terhadap perusahaan yang memenuhi aspek kepatuhan syariah dan masuk ke dalam daftar ISSI.

Secara umum saham yang patuh syariah menghasilkan abnormal return yang positif pada $\mathrm{h}+1 \mathrm{dan} \mathrm{h}+5$. Abnormal return yang negatif bisa muncul dikarenakan adanya dugaan ketakutan dari para investor trading terhadap saham yang terus menerus menerus, sehingga ketika saham sudah menghasilkan abnormal return yang postif, para trader menjual saham yang mereka miliki. Selain itu, informasi kepatuhan syariah ini sangat penting terutama bagi para manajer investasi syariah, dimana mereka diwajibkan untuk menginvestasikan dana pada saham-saham yang patuh syariah saja. Informasi ini merupakan langkah awal para manajer investasi dalam menentukan kemana dana akan diinvestasikan. Para manajer investasi syariah tetap harus membeli produk-produk yang syariah dan mulai menjual saham yg sudah tidak lagi patuh syariah dalam janga waktu 10 hari setelah pengumuman ISSI. Sehingga kemudian tidak mengherankan jika harga saham perusahaan patuh syariah meningkat dikarenakan oleh informasi yang ditanggapi secara positif oleh para manajer investasi dengan melakukan pembelian saham-saham perusahaan yang patuh syariah yang menyebabkan abnormal return terdorong naik secara drastis pada hari kelima. 
FINANCE: a Research Journal on Islamic Finance Vol.07 No. 02 Desember 2021 http//jurnal.radenfatah.ac.id/index.php/i-finance

Ellysa, Sigid dan Saiful.........Reaksi Pasar Atas Pengungkapan Kepatuhan Syariah

Selain itu, reaksi positif pasar yang tercermin dari abnormal return yang positif dan signifikan tidak selalu terjadi atau terlihat pada jendela peristiwa yang sama pada setiap pengujian. Kondisi ini mengindikasikan kecepatan dari reaksi pasar itu sendiri. Mengingat uji pasar efisien semi strong form adalah untuk mengetahui seberapa cepat harga melakukan penyesuaian atas informasi publik, maka informasi publik seperti pengumuman perubahan komposisi saham pada ISSI tentunya berdampak pada perusahaan yang patuh syariah dengan kecepatan penyesuaian harga yang berbeda-beda.

Penelitian ini sejalan dengan penelitian sebelumnya bahwa pengumuman kepatuhan syariah pada perusahaan dimana perusahaan tersebut dimasukkan ke dalam indeks syariah dikarenakan patuh syariah mendapatkan reaksi pasar yang positif (Jaballah et al., 2018; Yazi, 2015; Sherif \& Lusyana, 2017).

\section{KESIMPULAN}

Pengamatan yang dilakukan pada jangka waktu panjang yaitu sejak Indeks Saham Syariah Indonesia diluncurkan pada tahun 2011 hingga tahun 2019 menunjukkan mayoritas hipotesis $1\left(\mathrm{H}_{1}\right)$ diterima. Pengujian reaksi pasar terhadap harga saham atas pengungkapan kepatuhan syariah pada pengumuman perubahan komposisi saham dalam penghitungan Indeks Saham Syariah Indonesia menunjukkan hasil nilai abnormal return yang positif sebanyak 86\% atau 12 dari 14 pengujian yang tersedia, yang artinya terdapat reaksi pasar yang positif terhadap saham perusahaan yang patuh syariah. Masuknya perusahaan ke dalam Indeks Saham Syariah Indonesia dianggap sebagai sinyal positif oleh para investor, terutama bagi investor ritel dan manajer investasi yang mengkhususkan diri atau hanya fokus untuk menyalurkan dananya pada produk yang memenuhi aspek syariah saja. Sinyal positif ini kemudian disikapi dengan melakukan pembelian atas saham-saham patuh syariah tersebut.

Pada hasil pengujian hipotesis menunjukkan bahwa pengungkapan kepatuhan syariah memiliki nilai informasi yang sangat penting bagi investor dalam menentukan pilihan investasinya di pasar saham, terutama bagi investor yang memang memfokuskan atau mengkhususkan diri pada penyaluran dana investasi pada produk yang memenuhi aspek syariah saja. Adanya informasi kepatuhan syariah yang merupakan informasi publik memberikan sinyal kepada investor dimana sinyal tersebut akan membuat investor bereaksi, reaksi dari investor atau reaksi pasar inilah yang kemudian akan berdampak terhadap naik atau turunnya harga saham. Di sisi lain, berdasarkan kondisi ini bisa disimpulkan bahwa pasar modal Indonesia merupakan pasar modal efisien dengan semi strong form atau pasar modal efisien bentuk setengah kuat.

\section{REFERENSI}

Abdalloh, I. (2018). Pasar Modal Syariah. Jakarta: PT. Elex Media Komputindo.

Alhomaidi, A., Hassan, M. K., Zirek, D., \& Alhassan, A. (2018). Does an Islamic Label Cause Stock Price Comovements And Commonality In Liquidity? Applied Economics, 50(59). https://doi.org/10.1080/00036846.2018.1486023

Apriyanti, H. W. (2019). Perkembangan Industri Perbankan Syariah di Indonesia: Analisis Peluang dan Tantangan. Maksimum, 7(1). https://doi.org/10.26714/mki.7.1.2017.1623

Che Azmi, A., \& Hanifa, M. H. (2015). The Sharia-compliance of financial Reporting Practices: A Case Study on Waqf. Journal of Islamic Accounting and Business Research, 6(1). https://doi.org/10.1108/JIABR-10-2012-0069 
FINANCE: a Research Journal on Islamic Finance Vol.07 No. 02 Desember 2021 http//jurnal.radenfatah.ac.id/index.php/i-finance

Ellysa, Sigid dan Saiful........Reaksi Pasar Atas Pengungkapan Kepatuhan Syariah

Dzakiyuddin, A., \& Sutopo, B. (2020). Sharia Disclosure and Market Value: Study of List of Sharia Effect (DES) in Indonesia. International Journal of Accounting, Finance and Business (IJ AFB), 5(26).

Fauzan, M., \& Suhendro, D. (2018). Peran Pasar Modal Syariah dalam Mendorong Laju Pertumbuhan Indonesia. Jurnal Ekonomi Dan Bisnis Islam, 5(1), 33-44. http://jurnal.uinsu.ac.id/

Gujarati, D. N. (2012). Dasar-dasar Ekonometrika book 2. In Salemba Empat.

Hartono, J. (2017). Teori Portofolio dan Analisis Investasi (edisi Kesebelas). Yogyakarta: BPFE.

Hidayat, T. (2011). Buku Pintar Investasi Syariah. Jakarta: Media Kita.

Jaballah, J., Peillex, J., \& Weill, L. (2018). Is Being Sharia Compliant Worth It? Economic Modelling, 72. https://doi.org/10.1016/j.econmod.2018.02.011

Khairan, K. (2019). Kontribusi Pasar Modal Syariah dalam Pertumbuhan Ekonomi Indonesai. At-Tamwil: Kajian Ekonomi Syariah, 1(1), 98-114. https://ejournal.iaitribakti.ac.id/index.php/perbankan/article/view/876

Kumar, A., Page, J. K., \& Spalt, O. G. (2011). Religious Beliefs, Gambling Attitudes, and Financial Market Outcomes. Journal of Financial Economics, 102(3). https://doi.org/10.1016/j.jfineco.2011.07.001

Pacicco, F., Vena, L., \& Venegoni, A. (2018). Event Study Estimations Using Stata: The Estudy Command. Stata Journal, 18(2). https://doi.org/10.1177/1536867x1801800211

Reilly, Frank K., Brown, K. C. (2019). Investment Analysis Portfolio Management. In Journal of Chemical Information and Modeling (Vol. 53, Issue 9).

Sawidji, W. (2012). Cara Sehat Investasi di Pasar Modal. In PT. Jumalindi Aksara Grafika, Jakarta.

Sherif, M., \& Lusyana, D. (2017). Shariah -Compliant Investments and Stock Returns: Evidence from the Indonesian Stock Market. Journal of Islamic Accounting and Business Research, 8(2).

Sujana, I. N. (2017). Pasar Modal yang Efisien. Ekuitas: Jurnal Pendidikan Ekonomi, 5(2). https://doi.org/10.23887/ekuitas.v5i2.12753

Uhl, M. W. (2014). Reuters Sentiment and Stock Returns. Journal of Behavioral Finance, 15(4), 287-298. https://doi.org/10.1080/15427560.2014.967852

Yanti, F. (2012). Pengujian Abnormal Return Saham Sebelum dan Sesudah Peluncuran Indeks Saham Syariah Indonesia. Jurnal Manajemen, 01(September).

Yazi, E. (2015). The Effects of Shariah Compliance Announcement towards Stock Price Changes in Malaysia. Journal of Economics, Business and Management, 3(11). https://doi.org/10.7763/joebm.2015.v3.327 